Received 02.06.2016 Reviewed $\quad 10.08 .2016$ Accepted 02.09.2016

A - study design

B - data collection

C - statistical analysis

D - data interpretation

$\mathbf{E}$ - manuscript preparation

$\mathbf{F}$ - literature search

\section{Efficiency of some meteorological drought indices in different time scales, case study: wadi Louza basin (NW-Algeria)}

\author{
Fayçal DJELLOULI ${ }^{\text {ABCDEF }}$, Abderrazak BOUANANI ${ }^{\text {ADF }}$, \\ Kamila BABA-HAMED ${ }^{\mathrm{F}}$
}

University of Tlemcen, Laboratory No. 25, BP119, 13000, Tlemcen, Algeria; e-mail: fdjellouli@yahoo.com; a_bouananidz@yahoo.fr; kambabahamed@yahoo.fr

For citation: Djellouli F., Bouanani A., Baba-Hamed K. 2016. Efficiency of some meteorological drought indices in different time scales, case study: wadi Louza basin (NW-Algeria). Journal of Water and Land Development. No. 31 p. 33-41. DOI: 10.1515/jwld-2016-0034.

\begin{abstract}
Drought is an insidious hazard of nature in many parts of the world. It originates from persistent shortage of precipitation over a specific region for a specific period of time and has a conceptual and operational definition. Drought impact on some activity, group, or environmental sector depends on the extent of water shortage and ground conditions. Algeria and especially the western region has experienced several periods of drought over the last century, since 1975 to the present day. The most recent drought in 1981, 1989, 1990, 1992, 1994 and 1999 was characterized by its intensity and spatial extent. Drought is identified using various drought indices (meteorological, hydrological and agricultural). In this research, we focus on the meteorological drought, to assess the reliability of these indices under changing climatic conditions. Data was recorded for the period of 1980-2009 at wadi Louza catchment (NW-Algeria). For describing and monitoring drought severity periods, we calculated the correlation between both meteorological drought indices: Standardised Precipitation Index (SPI) and Effective Drought Index $(E D I)$. The results show that the watershed of wadi Louza has experienced a severe meteorological drought. The correlation between meteorological drought indices was good for all time steps and the best was found for 9-month time step. The obtained results may provide some scientific support for fighting against droughts.
\end{abstract}

Key words: drought, effective drought index, standardised precipitation index, wadi Louza

\section{INTRODUCTION}

Droughts are one of the most dangerous and damage-causing natural phenomena. Compared with the mean sum of precipitation in the last three decades of the 20th century, the mean sum of precipitation in growing seasons (April-September) of the years 2011-2050 is predicted to decrease by $55 \mathrm{~mm}$ [BĄK, ŁABĘDZKI 2014]

Many semi-arid areas (e.g. The Mediterranean basin, Western United States, South Africa and north-eastern Brazil) will suffer a decrease in water resources due to climate change. By 2020, between 75 and 250 million people in Africa are projected to be exposed to increased water stress due to climate change. In some countries, yields from rain-fed agriculture could be reduced by up to $50 \%$. Increases in the frequency and severity of floods and droughts are projected to adversely affect sustainable development. Drought affected areas are projected to increase in extent, with the potential for adverse impacts on multiple sectors, e.g. agriculture, water supply, energy production and health [IPCC 2007].

Over the years, more than 150 different drought indicators have been proposed and developed for drought characterization [ZARGAR et al. 2011]. Sever- 
al studies used Palmer Drought Severity Index (PDSI) [PALMER 1965], Surface Water Supply Index (SWSI) [SHAFER, DEZMAN 1982], Standardised Precipitation Index (SPI) [MCKEE et al. 1993], Effective Drought Index (EDI) [BYUN, WILHITE 1999], Reconnaissance Drought Index $(R D I)$ [TSAKIRIS et al. 2007]. A large number of drought indices are calculated using more hydro-meteorological variables [RAZIEI et al. 2009].

In the present research, our interest to assessment and monitoring drought severity in wadi Louza watershed (NW-Algeria). We used both indexes SPI and EDI.

The most prominent and widely used drought indicator is the Standardised Precipitation Index (SPI), which has been recommended to be used to characterize the meteorological droughts around the world by the World Meteorological Organization (WMO) due to its flexibility for various time scales, simplicity in input parameters and calculation, as well as effectiveness in decision making [SHEFFIELD, WOOD 2011; HAYES et al. 2011]. The SPI is determined by precipitation at different time scales (e.g. 1 month, 3 months, 12 months) [MCKEE et al. 1993; 1995].

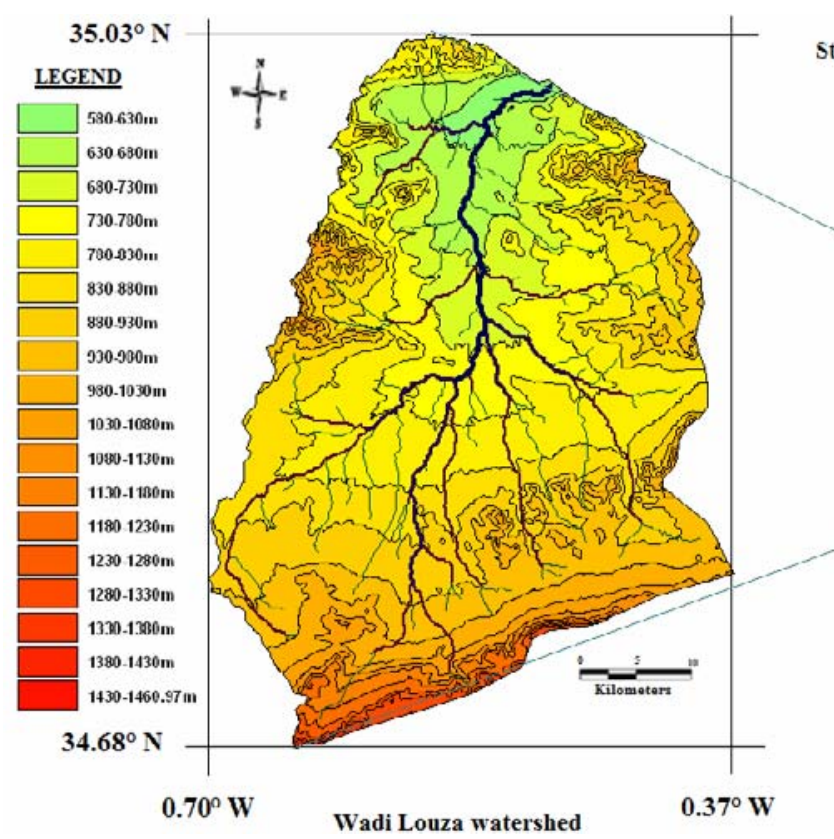

\section{DATA USED}

In this paper, all chosen precipitation stations (Telagh, Merine, Sid Ahmed) (Fig. 2) show the quality of good data, are managed by the National Agency of Hydric Resources (NAHR) (Tab. 1). Some gaps are observed in the time series of Sid Ahmed station. Data homogeneity was tested using Pettit test and Hubert test [HUBERT, CARBONNEL 1987; HUBERT et al. 1989]. Indeed, the average rupture in rainfall series, is detected only by the test of Hubert, characterized by an increase in rainfall. It's occurred in 2007.
In a comparative study between $E D I$ and $S P I$, the $E D I$ was found to be better than SPI in detecting long term, extremely long term and short term drought, short term rainfall and also dealing with the problem of overestimation and under estimation [BYUN, KIM 2010]

\section{METHOD AND MATERIAL}

\section{STUDY AREA}

The wadi Louza catchment is situated within the wadi Hammam basin north west of Algeria, between north latitudes of $34.68^{\circ}-35.03^{\circ}$ and the west longitudes of $0.70^{\circ}-0.37^{\circ}$, with an area of $746 \mathrm{~km}^{2}$. The main watercourse originates at an altitude of $1455 \mathrm{~m}$ on the fallout of mountain Mezioud. The main tributaries are Telzaa River, Telagh River, Neksifia River, Teghalimet River, then Louza River with a total length of about $39.51 \mathrm{~km}$ and elevations ranging from $580 \mathrm{~m}$ to $1460 \mathrm{~m}$ (the average elevation is $855 \mathrm{~m}$ ). Its climate is classified as semi-arid, with a mean precipitation of $286 \mathrm{~mm} \cdot$ year $^{-1}$ (1980-2009) (Fig. 1). 
Table 1. Characteristics of rainfall stations in wadi Louza basin

\begin{tabular}{|l|l|c|c|c|c|}
\hline $\begin{array}{c}\text { Station } \\
\text { name }\end{array}$ & $\begin{array}{l}\text { Gauge } \\
\text { type }\end{array}$ & Longitude & Latitude & $\begin{array}{c}\text { Elevation } \\
\mathrm{m}\end{array}$ & $\begin{array}{c}\text { Selected } \\
\text { period }\end{array}$ \\
\hline Telagh & $\begin{array}{l}\text { rain } \\
\text { gauge }\end{array}$ & $0^{\circ} 34^{\prime} 28.9726^{\prime \prime} \mathrm{W}$ & $34^{\circ} 47^{\prime} 4.9442^{\prime \prime} \mathrm{N}$ & 889 & $\begin{array}{c}1980- \\
2009\end{array}$ \\
\hline Merine & $\begin{array}{l}\text { rain } \\
\text { gauge }\end{array}$ & $0^{\circ} 24^{\prime} 12.1733^{\prime \prime} \mathrm{W}$ & $34^{\circ} 47^{\prime} 34.5859^{\prime \prime} \mathrm{N}$ & 959 & $\begin{array}{c}1980- \\
2009\end{array}$ \\
\hline $\begin{array}{l}\text { Sid } \\
\text { Ahmed }\end{array}$ & $\begin{array}{l}\text { rain } \\
\text { gauge }\end{array}$ & $0^{\circ} 32^{\prime} 41.3488^{\prime \prime} \mathrm{W}$ & $34^{\circ} 57^{\prime} 54.1487^{\prime \prime} \mathrm{N}$ & 653 & $\begin{array}{c}1980- \\
2009\end{array}$ \\
\hline
\end{tabular}

Source: own elaboration.

\section{METHODS}

Both meteorological drought indices have used for this research: the Standardised Precipitation Index $(S P I)$ and the Effective Drought Index (EDI); for objective to investigate and confirm the pertinence of these indices and estimate the impact of climate change on the water cycle of wadi Louza basin. These drought indices were calculated for each station based on monthly data, recorded for 1980 to 2009 .

\section{Drought indices}

\section{Standardised Precipitation Index (SPI)}

SPI should be used to characterize the meteorological droughts around the world by the World Meteorological Organization (WMO) [HAYES et al. 2011]. SPI is developed by [MCKEE et al. 1993] for the quantifying precipitation deficit for multiple time steps (e.g. 1-month, 3-months, 12-months), identifying dry and wet events and evaluate their intensity [BARTCZAK et al. 2014]. A long-term precipitation record is fitted to a probability distribution (e.g. Gamma distribution) and the cumulative probability of an observed precipitation event for each time scale of interest is deduced, The value of SPI can be obtained by transformation of the cumulative probability to the standard normal random variable with mean of zero and variance of one [JAIN et al. 2015], SPI varies between +2.0 and -2.0 , with extremes outside this range occurring in 5\% of the time [EDWARDS, MCKEE 1997].

SPI may be used for monitoring both dry and wet conditions. The greater value of $S P I$ close to 1 or above indicates the wet event. The SPI value shows: The near normal precipitation events $(-0.99 \leq S P I \leq$ $0.99)$, moderately dry $(-1.49 \leq S P I \leq-1.0)$, severely dry $(-1.99 \leq S P I \leq-1.5)$ and extremely dry $(S P I \leq$ -2.0) (Tab. 2). A drought event of the time scale is defined here as a period in which the $S P I$ is continuously negative and the $S P I$ reaches a value of -1.0 or less and ends when SPI becomes positive again [MCKEE et al. 1993]. The SPI at different time scales may vary in its usefulness in drought monitoring. In the case of shorter time scales (e.g. 1-month and 3-months), the $S P I$ values have the tendency to fluctuate frequently above and below the zero line, while for longer time scales (e.g. 12-months and 24-months) there are well-defined dry and wet cycles [IONITA et al. 2016].
Table 2. Classification of Standardised Precipitation Index $(S P I)$ values

\begin{tabular}{|l|l|}
\hline SPI value & Drought condition \\
\hline$\geq 2.0$ & extremely wet \\
\hline$\langle 1.5 ; 1.99\rangle$ & very wet \\
\hline$\langle 1.0 ; 1.49\rangle$ & moderately wet \\
\hline$\langle-0.99 ; 0.99\rangle$ & near normal \\
\hline$\langle-1.0 ;-1.49\rangle$ & moderately dry \\
\hline$\langle-1.5 ;-1.99\rangle$ & severely dry \\
\hline$\leq-2.0$ & extremely dry \\
\hline
\end{tabular}

Source: MCKEE et al. [1993], modified.

The calculation for SPI is given with under equation (1) [NoROUZI et al. 2012];

$$
S P I=\frac{x_{i, j}-\bar{x}}{\sigma}
$$

where, $x=$ the seasonal precipitation at the $i^{\text {th }}$ rain gauge and $j^{\text {th }}$ observation, $\bar{x}=$ the long-term seasonal mean and $\sigma=$ standard deviation, $S P I=$ Standardised Precipitation Index.

\section{Effective drought index (EDI)}

BYUN and WILHITE [1999] proposed Effective Drought Index $(E D I)$, is a reply and have the potential to deal with all of the limitations of SPI. EDI provides more information's: duration and severity of rainfall deficit,start and end of the drought period. Effective precipitation $(E P)$ that represents resources daily depletion of water is the base of concept $E D I$ [MORID et al. 2006]. The original form of EDI is computed with a daily time step using daily rainfall data. SMAKHTIN and HUGHES [2007] modified his algorithm to be tested with monthly data.

An innovative discovery in the field of drought research has provided by BYUN and WILHITE [1999], confirmed by BYUN and LEE [2002], YAMAGUCHI and SHINODA [2002], HAN and BYUN [2006] and CHOI and BYUN [2007].

BYUN and WILHITE [1999] suggested the following equation for $E P$ :

$$
E P_{i}=\sum_{n=1}^{i}\left[\left(\sum_{m=1}^{n} P_{m}\right) / n\right]
$$

where: $E P_{i}=$ valid effective precipitation, $P_{m}=$ daily precipitation, $m=$ number of days before a specific day, $i=$ the number of days of the time window, $n=$ running from 1 till $i$ [CHHAJER et al. 2015].

$$
D E P=E P-M E P
$$

$E P=$ effective precipitation for 365 days counting from a specific day, $M E P=$ the mean of effective precipitation $D E P=$ deviation of $E P$ from $M E P$.

$E D I$ is calculated as,

$$
E D I=D E P / S D(E P)
$$

$S D(E P)=$ the standard deviation of each day's $E P$. 
Ranks of EDI reflect drought conditions [BYUN, WILHITE 1999] indicate: extreme drought ( $E D I \leq$ $-2.0)$, severe drought $(-1.99 \leq E D I \leq-1.5)$, moderate drought $(-1.49 \leq E D I \leq-1.0)$ and near normal conditions $(-0.99 \leq E D I \leq 0.99)$.

\section{RESULTS AND DISCUSSIONS}

\section{CORRELATION ANALYSIS BETWEEN METEOROLOGICAL INDICES}

Pearson correlation coefficient and the linear regressions between the monthly values of the $S P I$ versus the $E D I$ were calculated for three chosen stations. Figure 3 was prepared to spot trends and correlations between the SPIS and EDIs indices, the scatter diagram of $S P I 1$ and $E D I 1$ is very scattered and more tightly for SPI9 and EDI9. The results showed, the maximum value of $(r)$ between SPIS and EDIs was obtained for 9-months time scale, showed a good relationship in terms of this time scale and the minimum value of 1-month time scale in all areas (Tab. 3). On a time scale 3, 6 and 12-months in all stations, correlation coefficient $(r)$ is greater than 0.73 .

\section{ASSESSMENT OF DROUGHT CHARACTERISTICS}

The assessment, the prediction and mitigation are needed in order to quantify drought. The severity and duration characterized drought. During the period 1980-2009, SPI and EDI are used to these objectives in wadi Louza basin.

\section{For short-term drought}

In Sid Ahmed region, the EDI is the major in the maximum duration of the drought and in number of drought months. In Merine region, the longest drought among all events measured using SPI1 and SPI3 is 51 months and 63 months respectively (Tab. 4). The number of drought months grew with the increase of time step for SPI, but, for EDI decrease and the maximum duration of drought varies for each station.
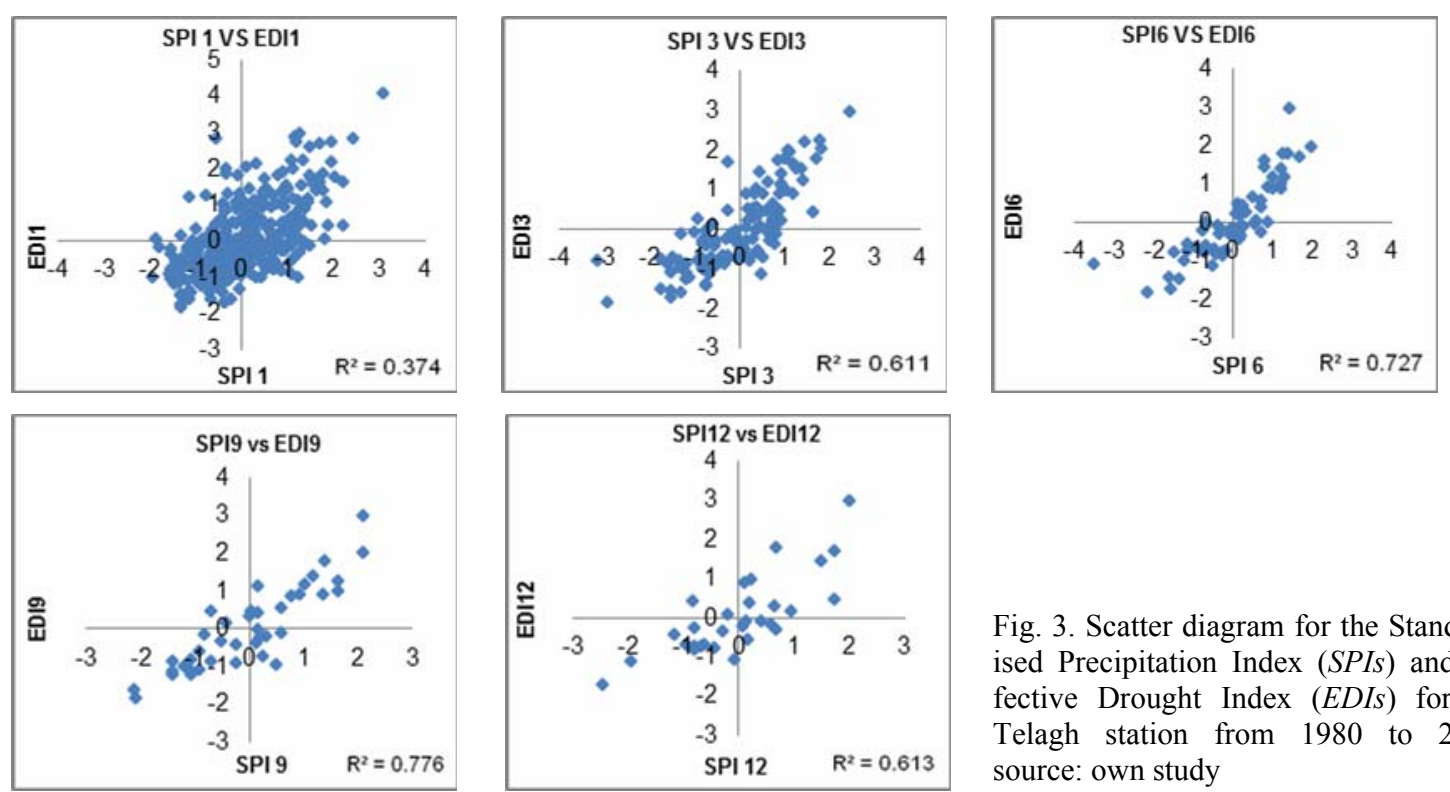

Fig. 3. Scatter diagram for the Standardised Precipitation Index $(S P I S)$ and Effective Drought Index (EDIs) for the Telagh station from 1980 to 2009; source: own study

Table 3. Correlation coefficient $(r)$ between Standardised Precipitation Index (SPIS) and Effective Drought Index (EDIs) in different time scales (1, 3, 9 and 12 months)

\begin{tabular}{|c|c|c|}
\hline Scale time & Region & $r$ \\
\hline \multirow{3}{*}{$S P I 1$ vs $E D I 1$} & Telagh & 0.61 \\
\hline & Sid Ahmed & 0.64 \\
\hline & Merine & 0.61 \\
\hline \multirow{3}{*}{$S P I 3$ vs $E D I 3$} & Telagh & 0.78 \\
\hline & Sid Ahmed & 0.85 \\
\hline & Merine & 0.81 \\
\hline \multirow{3}{*}{$S P I 6$ vs $E D I 6$} & Telagh & 0.85 \\
\hline & Sid Ahmed & 0.85 \\
\hline & Merine & 0.84 \\
\hline \multirow{3}{*}{$S P I 9$ vs $E D I 9$} & Telagh & 0.88 \\
\hline & Sid Ahmed & 0.84 \\
\hline & Merine & 0.84 \\
\hline \multirow{3}{*}{$S P I 12$ vs $E D I 12$} & Telagh & 0.78 \\
\hline & Sid Ahmed & 0.73 \\
\hline & Merine & 0.74 \\
\hline
\end{tabular}

Source: own study.
As showed in Figure 4, the maximum duration of droughts detected by EDI1s, which occurred from April 1988 to February 1989, observed in Sid Ahmed area. That was the initial stage of a moderate drought event, followed by a severe shortage of rainfall in winter, spring and summer, began in December 1999, of 9 months duration. SPI1s which is the most similar to the EDI1s, was able to detect in this short-term drought the most severe droughts months (November 1981 and March 1997) in all regions during the period of study. For 1-month time scale, it can be seen 10$14 \%$ the total number of months with $S P I<-1$ and $11-17 \%$ with $E D I<-1$ belong to moderate, severe or extreme drought classes. Succession of dry months varies from 1-month minimum to 11 months maximum. Less accurate forecasts are the result of sensitivity the SPI1 to variation in precipitation from month to month. 
Table 4. Drought monitoring with SPIs and EDIs indices for short-term (1 and 3 months) in wadi Louza watershed

\begin{tabular}{|c|c|c|c|c|c|c|c|c|c|c|c|c|}
\hline \multirow{3}{*}{ Station } & \multicolumn{12}{|c|}{ Number of } \\
\hline & \multicolumn{2}{|c|}{$\begin{array}{l}\text { drought months } \\
\text { acc. to }\end{array}$} & \multicolumn{2}{|c|}{$\begin{array}{l}\text { drought events } \\
\text { acc. to }\end{array}$} & \multicolumn{2}{|c|}{$\begin{array}{l}\text { maximum dura- } \\
\text { tion of drought } \\
\text { (months) acc. to }\end{array}$} & \multicolumn{2}{|c|}{$\begin{array}{l}\text { drought months } \\
\text { acc. to }\end{array}$} & \multicolumn{2}{|c|}{$\begin{array}{l}\text { drought events } \\
\text { acc. to }\end{array}$} & \multicolumn{2}{|c|}{$\begin{array}{l}\text { maximum dura- } \\
\text { tion of drought } \\
\text { (months) acc. to }\end{array}$} \\
\hline & SPI1 & $E D I 1$ & $S P I 1$ & $E D I 1$ & SPI1 & $E D I 1$ & $S P I 3$ & $E D I 3$ & $S P I 3$ & $E D I 3$ & $S P 13$ & $E D I 3$ \\
\hline Telagh & 35 & 41 & 26 & 12 & 3 & 9 & 51 & 42 & 13 & 8 & 12 & 12 \\
\hline Sid Ahmed & 38 & 59 & 31 & 15 & 3 & 11 & 60 & 57 & 16 & 10 & 9 & 12 \\
\hline Merine & 51 & 44 & 35 & 18 & 4 & 8 & 63 & 48 & 17 & 11 & 9 & 9 \\
\hline
\end{tabular}

Explanations: SPI1, SPI3 = Standardised Precipitation Index in 1-month time scale and 3-months time scale, respectively; EDI1, EDI3 = Effective Drought Index in 1-month time scale and 3-months time scale, respectively.

Source: own study.

Figure 5 shows a comparison of the EDI3s with the SPI3s over the same period. Both indices indicated severe and moderate event was relieved between May 1983 to November 1983 in Merine and Sid Ahmed areas. As the drought period lengthened, was 12 months continuous, occurred from December 1982 to November 1983 at Sid Ahmed region.

$S P I 3$ s and EDI3s showed extreme drought period (September 1981 to November 1981) in all areas. SPI3s indicated the extreme drought event with SPI value -2.82 at $\mathrm{Sid}$ Ahmed, -3.16 at Telagh and -2.35 at Merine, but EDI3 showed the extreme drought just in Sid Ahmed with EDI3 value -2.15. At all stations, SPI3s and EDI3s upheld the period between December 1995 to December 1996 is the wetly duration. September 2008 to February 2009 is identified as the wet months by SPI3s but EDI3s extended this phase to May 2009, confirm the average rupture in rainfall series detected by Hubert test, characterized by an increase in rainfall.

The difference between $S P I$ and $E D I$ for time scale 1-month and 3-month. EDI can be detected succession period (dry or wet) but the SPI overestimates intensity of the (dry or wet) event.

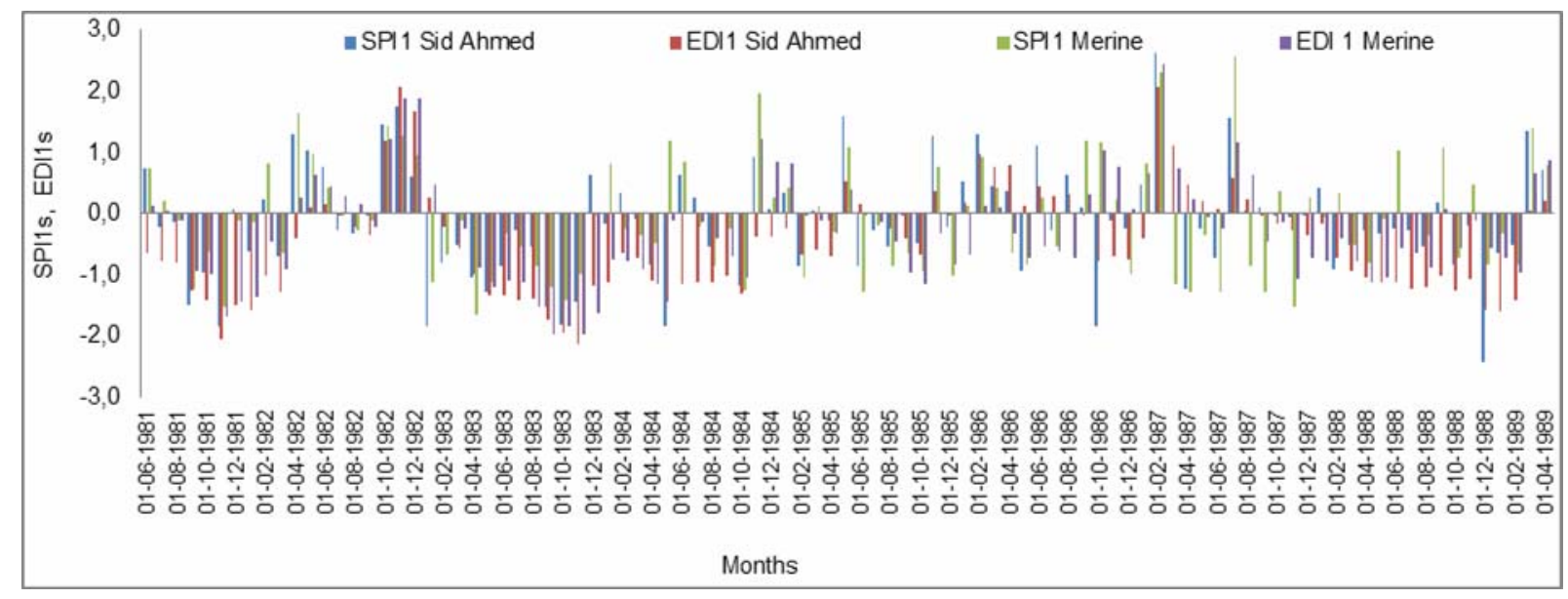

Fig. 4. Comparison of the Standardised Precipitation Index (SPI $1 s)$ and Effective Drought Index (EDI1s) for Merine and Sid Ahmed stations with a one month time step during period 1981 to 1989; source: own study

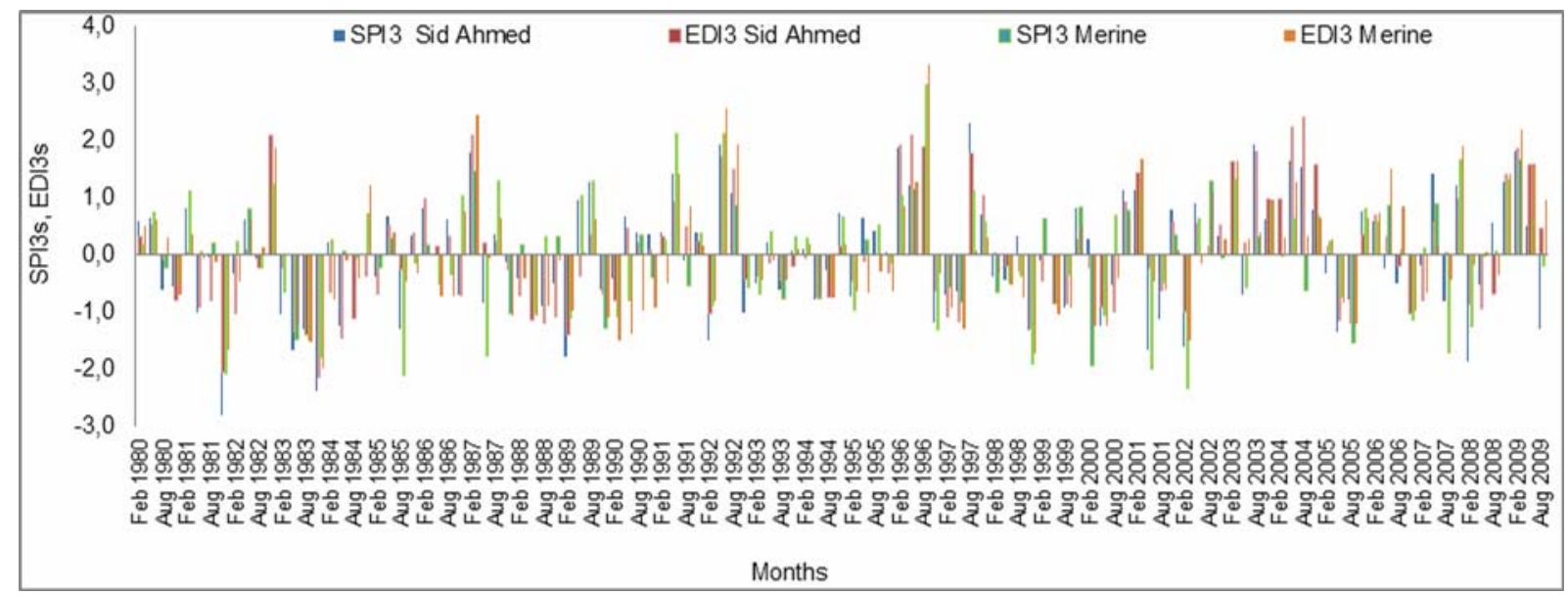

Fig. 5. Comparison of the Standardised Precipitation Index (SPI3s) and Effective Drought Index (EDI3s) for Merine and Sid Ahmed station with a 3-months time scale; source: own study 


\section{For average- and long-term drought}

The SPI9s show similar behaviour to the EDI9s as can be identified visually, reveal the same severity of dry and wet cases (Fig. 6a, b, c).
For each index, there were 18 months is the maximum duration of the drought, started in March 1983, ended in August 1984 with the monthly EDI and SPI were $<-1$ (Tab. 5).
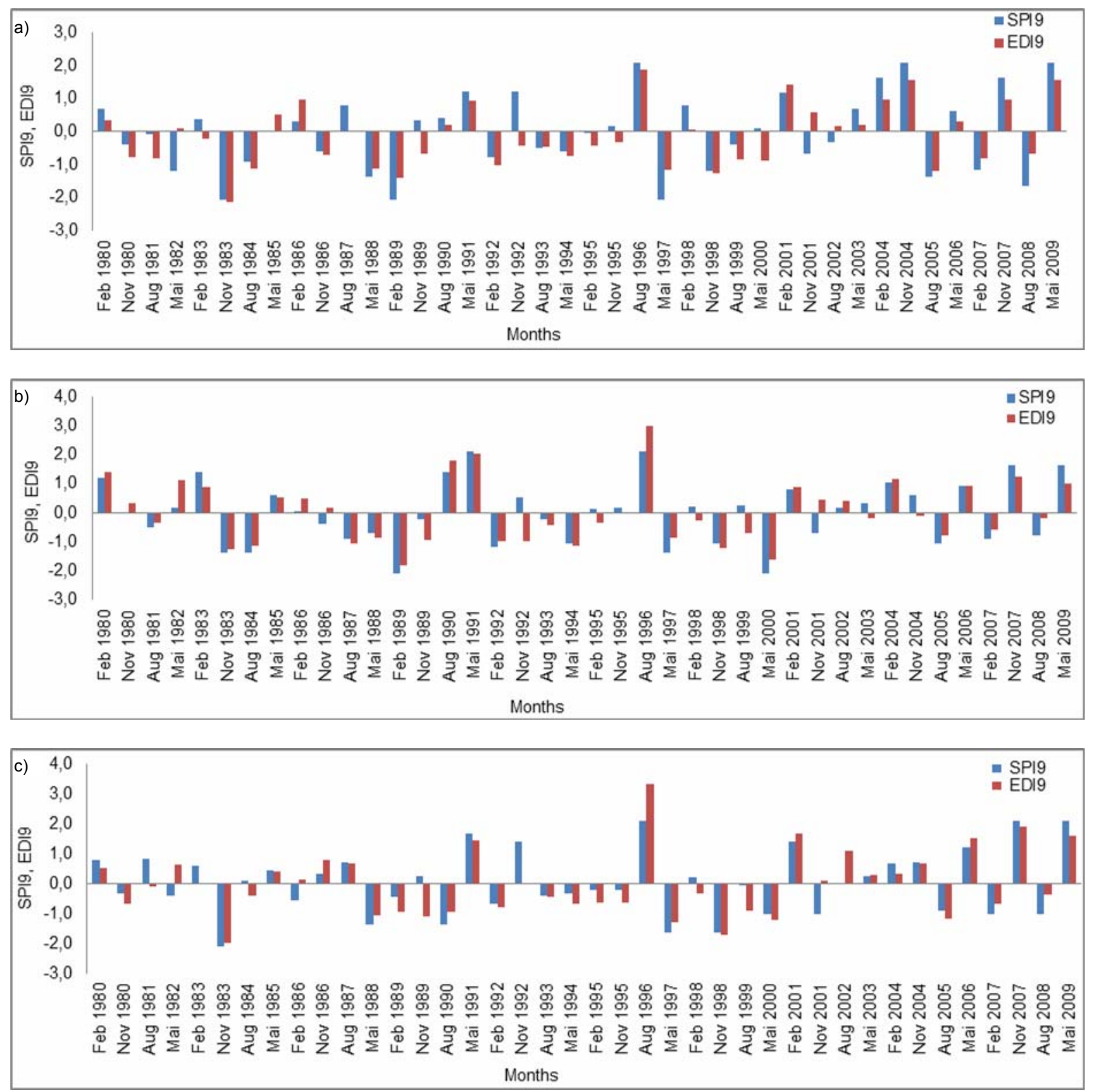

Fig. 6. Comparison of the Standardised Precipitation Index (SPI9) and Effective Drought Index (EDI9) values with a 9-months time scale for: a) Sid Ahmed station b) Telagh, c) Merine; source: own study

Table 5. Drought monitoring with SPIs and EDIs indices for average and long-term ( 9 and 12 months) in wadi Louza watershed

\begin{tabular}{|c|c|c|c|c|c|c|c|c|c|c|c|c|}
\hline \multirow{3}{*}{ Station } & \multicolumn{12}{|c|}{ Number of } \\
\hline & \multicolumn{2}{|c|}{$\begin{array}{l}\text { drought months } \\
\text { acc. to }\end{array}$} & \multicolumn{2}{|c|}{$\begin{array}{l}\text { drought events } \\
\text { acc. to }\end{array}$} & \multicolumn{2}{|c|}{$\begin{array}{l}\text { maximum dura- } \\
\text { tion of drought } \\
\text { (months) acc. to }\end{array}$} & \multicolumn{2}{|c|}{$\begin{array}{l}\text { drought months } \\
\text { acc. to }\end{array}$} & \multicolumn{2}{|c|}{$\begin{array}{l}\text { drought events } \\
\text { acc. to }\end{array}$} & \multicolumn{2}{|c|}{$\begin{array}{l}\text { maximum dura- } \\
\text { tion of drought } \\
\text { (months) acc. to }\end{array}$} \\
\hline & SPI9 & EDI9 & SPI9 & EDI9 & SPI9 & $E D I 9$ & $S P I 12$ & $E D I 12$ & SPI12 & $E D I 12$ & SPI12 & $E D I 12$ \\
\hline Telagh & 81 & 63 & 9 & 7 & 18 & 18 & 36 & 36 & 3 & 3 & 12 & 12 \\
\hline Sid Ahmed & 81 & 72 & 9 & 8 & 18 & 18 & 60 & 60 & 5 & 5 & 12 & 18 \\
\hline Merine & 81 & 63 & 9 & 7 & 9 & 9 & 60 & 24 & 5 & 2 & 12 & 12 \\
\hline
\end{tabular}

Explanations: SPI9, SPI12 = standardised precipitation index in 9-month time scale and 12-months time scale, respectively; EDI9, EDI12 = effective drought index in 9-month time scale and 12 -months time scale, respectively.

Source: own study. 
Best correlation was obtained between $S P I 9_{s}$ and EDI9s by Pearson correlation coefficient confirm the result, for 9-months time scale, it can be seen $20-23 \%$ of the total number of months with $S P I<-1$ and $16-20 \%$ with $E D I<-1$. In study basin, extreme drought events are identified for various stations. At Sid Ahmed, Telagh and Merine SPI value is -2.10 but $E D I$ value is -2.15 at Sid Ahmed. 9-months time scale is the most suitable time step to provide reasonable estimates of drought severity and capture the soil moisture anomalies [CHAMPAGNE et al. 2015; PAULO et al. 2012; JAIN et al. 2015].

In 12-months time step moderate droughts have been determined, by SPI: 4, 1, and 3 times, by EDI: 5 ,
2 and 1 times in Sid Ahmed, Telagh and Merine districts respectively. Severe drought has been identified 1 time for each station by SPI, but by EDI just in Telagh and Merine. During the period between 19822005 all stations indicate moderate to severe drought, except Sid Ahmed. In Telagh region extreme drought has been identified by peak value -2.44 (2000) (Fig. 7).

The drought intensity increase spatially in the study area,from Sid Ahmed Region (North) to Telagh Region (South) confirms the findings of of GHENIM and MEgNOUNIF [2013]. For time scale 9-months and 12-months, SPI and EDI show almost identical characteristics: frequency and intensity (drought or wet).

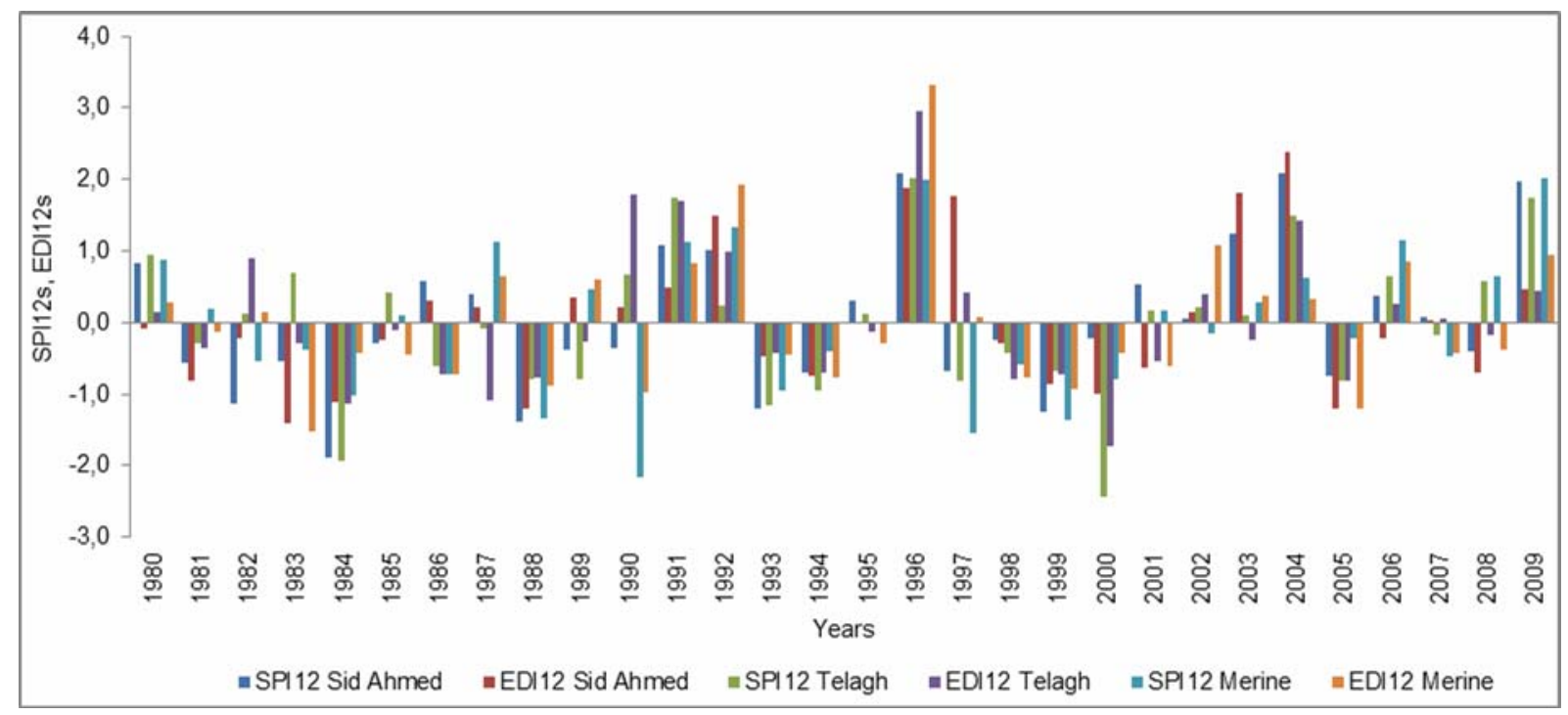

Fig. 7. Standardised Precipitation Index (SPI12s) and Effective Drought Index (EDI12s) values for selected stations with a 12-months time scale; source: own study

\section{CONCLUSIONS}

1. Identification of efficacious indices is referred to the capacity of SPI and EDI to be performed to forecast and assess drought severities of an appropriate time step, for short-term and long-term [MASHARI ESHGHABAD et al. 2014].

2. Sensitivities of $S P I$ to variation in precipitation decrease with the increase of time step.

3. The short-term SPIs (1-month and 3-months) overestimates intensity of the drought, may lead to an erroneous assessment.

4. In 9-months time step, SPIs had a high $R^{2}$ value, greater than 0.73 , was the closest to the EDIs.

5 . It could be concluded, at this long-term, $S P I$ and $E D I$ had almost the same drought severity and the maximum efficiency. This time scale is a better choice to detect the drought severity for study basin.

6. Two severe periods of drought have been detected: one, between March 1983 and August 1984 and the other between March 1988 and November 1989.

7. SPI has been recommended to be used to characterize the meteorological droughts around the world. For better understanding the drought attributes of the study area, it is recommended to integrate EDI into an emerging drought monitoring system and can serve as predictors of drought.

\section{REFERENCES}

BĄK B., ŁABĘDZKI L. 2014. Prediction of precipitation deficit and excess in Bydgoszcz Region in view of predicted climate change. Journal of Water and Land Development. No. 23 p. 11-19. DOI: 10.1515/jwld-2014-0025.

BARTCZAK A., GLAZIK R., TyszKowski S. 2014. The application of Box-Cox transformation to determine the Standardized Precipitation Index $(S P I)$, the Standardized Discharge Index $(S D I)$ and to identify drought events: Case study in Eastern Kujawy (Central Poland). Journal of Water and Land Development. No. 22 p. 3-15.

BYUn H.R., WiLHITE D.A. 1999. Objective quantification of drought severity and duration. Journal of Climate. Vol. 12 p. $2747-2756$.

ByUn H.R., LeE D.K. 2002. Defining three rainy seasons and the hydrological summer monsoon in Korea using available water resources index. Journal of Meteorological Society of Japan. Vol. 80. Iss. 11 p. 33-44.

BYUN H.R., KIM D.W. 2010. Comparing the Effective Drought Index and the Standardized Precipitation Index. 
In: Economics of drought and drought preparedness in a climate change context. López-Francos A. (comp.), López-Francos A. (collab.). Options Méditerranéennes. Sér. A. Séminaires Méditerranéens. No. 95. Zaragoza. CIHEAM / FAO / ICARDA / GDAR / CEIGRAM / MARM p. 85-89.

Champagne C., Davidson A., Cherneski P., L'Heureux J., HADWEN T. 2015. Monitoring agricultural risk in Canada using L-Band passive microwave soil moisture from SMOS. Journal of Hydrometeorology. Vol. 16 p. 5-18. DOI: 10.1175/JHM-D-14-0039.1.

ChHajer V., Prabhakar S., Rama Chandra Prasad P. 2015. Development of index to assess drought conditions using geospatial data a case study of Jaisalmer district, Rajasthan, India. Geoinformatica Polonica. Vol. 14. Iss. 1 p. $29-40$.

Chor K.S., Byun H.R. 2007. Definition of the onset and withdrawal of the warm season over East Asia and their Characteristics. Journal of Korean Meteorological Society. Vol. 43. Iss. 2 p. 143-159.

EDwARDS D.C., McKeE T.B. 1997. Characteristics of 20th century drought in the United States at multiple scales. Atmospheric Science Paper. No. 634 p. 1-30.

Ghenim A.N., Megnounif A. 2013. Spatial and temporal assessment of drought in northern Algeria. Seventeenth International Water Technology Conference, IWTC 17, 5-7 November 2013. Istanbul.

HAN S.U., BYUN H.R. 2006. The existence and the climatological characteristics of the spring rainy period in Korea. International Journal of Climatology. Vol. 26. Iss. 5 p. 637-654.

Hayes M., Svoboda M., Wall N., Widhalm M. 2011. The Lincoln Declaration on Drought Indices: Universal Meteorological Drought Index Recommended Bulletin of the American Meteorological Society. Vol. 92. Iss. 4 p. $485-488$.

Hubert P., CARBonnel J. P. 1987. Approche statistique de l'aridification de l'Afrique de l'Ouest [Statistical Approach to the Aridification of West Africa]. Journal of Hydrology. Vol. 95. Iss. 1-2 p. 165-183.

Hubert P., Servat E., Paturel J.E., Kouame B., Bendjoudi H., CARBonNel J.P., LubeSNiElH. 1998. La procédure de segmentation, dix ans après [The segmentation procedure, ten years after]. In: Water Resources Variability in Africa during the XXth Century. Proceedings Abidjan'98. Conference. November 1998. IASH Publ. No. 252 p. 395-409.

Ionita M., Scholz P., Chelcea S. 2016. Assessment of droughts in Romania using the Standardized Precipitation Index. Natural Hazards. Vol. 81. Iss. 3 p. $1483-$ 1498. DOI: $10.1007 / \mathrm{s} 11069-015-2141-8$.

IPCC 2007. Changements climatiques 2007: Rapport de synthése [Climate change 2007: Synthesis report]. ISBN 92-9169-222-0. Geneva, Switzerland pp. 104.

JAIN V.K., PANDEY R.P, JAIN M.K., BYUN H.R. 2015. Comparison of drought indices for appraisal of drought characteristics in the Ken River Basin. Weather and Climate
Extremes. Vol. 8. p. 1-11. DOI: 10.1016/J.WACE. 2015.05.002

MASHARi Eshghabad S., Omidvar E., Solaimani K. 2014. Efficiency of some meteorological drought indices in different time scales (Case study: Tajan Basin, Iran). ECOPERSIA. Vol. 2. Iss. 1 p. 411-453.

MCKeE T.B., DoESKEN N.J., KLEIST J. 1993.The relationship of drought frequency and duration to time scales. Eighth Conference on Applied Climatology. Anaheim, California. No. 1 p. 179-184.

McKee T.B., Doesken N.J., KLEIST J. 1995. Drought monitoring with Multiple Time Scales. 9th Conference on Applied Climatology. Dallas, Texas p. 233-236.

Morid S., Smakhtin V., Moghaddasi M. 2006. Comparison of seven meteorological indices for drought monitoring in Iran. International Journal of Climatology. Vol. 26. Iss. 8 p. $971-985$.

Norouzi A., Nohegar A., Ghorbani A. 2012. Comparison of the suitability of standardized precipitation index (SPI) and aggregated drought index (ADI) in Minab Watershed (Hormozgan Province/South of Iran). African Journal of Agricultural Research. Vol. 7. Iss. 44 p. 5905-5911.

PALMER W.C. 1965. Meteorological drought.Office of Climatology. U.S. Department of Commerce. Vol. 45 p. 158.

Paulo A.A., Rosa R.D., Pereira L.S. 2012. Climate trends and behaviour of drought indices based on precipitation and evapotranspiration in Portugal. Natural Hazards and Earth System Sciences. Vol. 12 p. 1481-1491. DOI: 10.5194/nhess-12-1481-2012.

Raziei T., Saghafian B., Paulo A.A., Pereira L.S., Bordi I. 2009. Spatial patterns and temporal variability of drought in western Iran. Water Resources Manage. Vol. 23 p. 439-455. DOI: 10.1007/s11269-008-9282-4.

Shafer B.A., Dezman L.E. 1982. Development of a Surface Water Supply Index (SWSI) to assess the severity of drought conditions in snowpack runoff areas. Proceedings of the Western Snow Conference p. 164-175.

ShefFIEL D.J., Wood E.F. 2011. Drought: past problems and future scenarios. London, UK, Washington, D.C., USA. Earthscan. ISBN 978-1-84971-082-4 pp. 224.

SMAKHTI V.U., HugheS D.A. 2007. Automated estimation and analyses of meteorological drought characteristics from monthly rainfall data. Environmental Modelling and Software. Vol. 22 p. 880-890.

Tsakiris G., Pangalou D., Vangelis H. 2007. Regional drought assessment based on the Reconnaissance Drought Index (RDI). Water Resource Manage. Vol. 21 p. 821-833.

YAMAGUCHI Y., SHINODA M. 2002. Soil moisture modeling based on multiyear observations in the Sahel. Journal of Applied Meteorology. Vol. 41. Iss. 11 p. 1140-1146.

Zargar A., SADiQ R., NASER B., Khan F.I. 2011. A review of drought indices. Environmental Review. Vol. 19 p. 333-349. 


\section{Fayçal DJELLOULI, Abderrazak BOUANANI, Kamila BABA-HAMED}

Efektywność niektórych wskaźników suszy meteorologicznej w różnej skali czasu na przykładzie zlewni uedu Louza w północno-zachodniej Algierii

\section{STRESZCZENIE}

Susza jest naturalnym zagrożeniem $\mathrm{w}$ wielu częściach świata. Powstaje wskutek trwałego ograniczenia ilości opadów w danym regionie i okresie czasu. Jest zdefiniowana w sensie konceptualnym i operacyjnym. Wpływ suszy na różne rodzaje działalności człowieka i na środowisko zależy od rozmiaru deficytu wody i od warunków glebowych. Algieria, szczególnie jej zachodnia część doświadczyła okresów intensywnej suszy już w ubiegłym wieku, począwszy od roku 1975 r., i doświadcza ich po dzień dzisiejszy. Ostatnia susza charakteryzowała się dużą intensywnością i przestrzennym zasięgiem. Suszę identyfikuje się, używając różnych wskaźników meteorologicznych, hydrologicznych lub rolniczych. W badaniach prezentowanych w niniejszej pracy skupiono się na suszy meteorologicznej, aby ocenić wiarygodność tych wskaźników w zmieniających się warunkach klimatycznych. Dane notowano w okresie 1980-2009 w zlewni uedu Louza w północno-zachodniej Algierii. Na potrzeby charakterystyki i monitoringu okresów suszy obliczono korelację między dwoma wskaźnikami - wskaźnikiem standaryzowanego opadu $(S P I)$ i efektywnym wskaźnikiem suszy $(E D I)$. Wyniki dowodzą że w zlewni uedu Louza wystąpiła głęboka susza meteorologiczna. Korelacja między wskaźnikami suszy meteorologicznej była dobra $\mathrm{w}$ odniesieniu do wszystkich kroków czasowych, ale najlepsza w odniesieniu do okresów 9-miesięcznych. Uzyskane wyniki mogą stanowić naukowe wsparcie w walce z suszą.

Słowa kluczowe: efektywny wskaźnik suszy, susza, ued Louza, wskaźnik standaryzowanego opadu 